\title{
Critical Notice
}

\section{Neoplatonism: The Last Ten Years}

The past decade or so has been an exciting time for scholarship on Neoplatonism. I ought to know, because during my stint as the author of the "Book Notes" on Neoplatonism for the journal Phronesis, I read most of what was published in the field during this time. Having just handed the Book Notes over to George Boys-Stones, I thought it might be worthwhile to set down my overall impressions of the state of research into Neoplatonism. I cannot claim to have read all the books published on this topic in the last ten years, and I am here going to talk about certain themes and developments in the field rather than trying to list everything that has appeared. So if you are an admirer, or indeed author, of a book that goes unmentioned, please do not be affronted by this silence-it does not necessarily imply a negative judgment on my part. I hope that the survey will nonetheless be wide-ranging and comprehensive enough to be useful.

I'll start with an observation made by Richard Goulet, ${ }^{1}$ which I have been repeating to students ever since I read it. Goulet conducted a statistical analysis of the philosophical literature preserved in the original Greek, and discovered that almost three-quarters of it (71\%) was written by Neoplatonists and commentators on Aristotle. In a sense this should come as no surprise. Late ancient philosophers were not only centuries closer to us in time, but were the gatekeepers who decided which texts from earlier antiquity would be copied, studied and thus preserved into the Byzantine period. We can thank the scholars of late antiquity for the fact that we are able to read the works of Plato, and blame them for the fact that we are unable to read the works of Chrysippus (which were after all still known to Galen in the second century). If academics apportioned their scholarly attention strictly in accordance with the sheer

1 In C. D'Ancona (ed.), The Libraries of the Neoplatonists (Leiden: Brill, 2007), at 48-9. 
quantity of surviving literature, then there would be more research on late antique philosophy than on Plato and Aristotle combined.

Obviously this is not the case, and in fact it is only relatively recently that the study of Neoplatonism has achieved wide acceptance as a part of the study of ancient philosophy in general. One can measure this by looking at surveys of ancient philosophy. It is still possible to see such books paying only scant attention to material later than the Hellenistic schools. ${ }^{2}$ But more commonly one will now find substantial coverage of Neoplatonists and other late antique authors. A good example is a recent Companion to Ancient Philosophy, ${ }^{3}$ which is divided into five parts, the last consisting of ten papers on philosophy in the Roman Imperial period and beyond. This change in attitude should help to ensure the health of the field in coming years. A crucial question here is whether doctoral students disadvantage themselves on the job market by writing a dissertation on, say, Plotinus or Proclus as opposed to, say, Plato or Aristotle. The answer may still be yes, but certainly the disadvantage would be far smaller now than it was when I was a beginning graduate student (twenty years ago, since you ask).

My impression is that in this respect the situation in Europe may be better than in North America. I was surprised when, in his introduction to the recent Cambridge History of Philosophy in Late Antiquity, the editor Lloyd Gerson argued for banning the use of the word "Neoplatonism" in part on the basis that it remains a term of abuse. ${ }^{4}$ My sense is that, to the contrary, "Neoplatonism" has become a useful and attractive brand name for the field. It may be that my disagreement with Gerson here has a geographical explanation. In France, Germany, and even Great Britain, there now seems to be no particular animus against "Neoplatonism," but perhaps the word does have a lingering pejorative connotation in Canada or the Us. While I would not wish to see the term fall into disuse, there is a strong argument for also using Gerson's preferred phrase "philosophy in late antiquity" or "late antique philosophy." Thanks to Peter Brown and others, historians now regularly speak of "late antiquity" as

2 For instance M.R. Wright, Introducing Greek Philosophy (Durham: Acumen, 2009) only touches on later antiquity in an epilogue.

3 F. Sheffield and J. Warren (eds), The Routledge Companion to Ancient Philosophy (London: Routledge, 2014).

4 L. Gerson (ed.), The Cambridge History of Philosophy in Late Antiquity, 2 vols (Cambridge: Cambridge University Press, 2010), 3. This effectively replaces the volume which was long a standard reference work, and which remains useful: A.H. Armstrong (ed.), The Cambridge History of Later Greek and Early Medieval Philosophy (Cambridge: Cambridge University Press, 1967). 
a distinct period. Thus the phrase helps relate the study of later ancient philosophy to the activity of scholars in other fields. Furthermore, a major development in our own field is the increasing attention paid to philosophers who were not Neoplatonists, but rather Gnostics and Christians. I would encourage the use of "late antique philosophy" as a useful umbrella term, which includes Neoplatonism but also other thinkers of the period.

In any event, Gerson's History exemplifies another welcome trend, which is the appearance of numerous handbooks and introductions to Neoplatonism or late ancient philosophy. Along with the Cambridge History we now have The Routledge Handbook of Neoplatonism. ${ }^{5}$ They complement each other well, in that the former is chronological in structure, with chapters devoted to individual thinkers or schools, whereas the latter is more thematic. Both publications, because of their size and collaborative nature, cover more ground than a monograph could take on. But several good single-author introductions have also appeared in the last decade. Acumen published two such books devoted respectively to Neoplatonism and the ancient commentators, ${ }^{6}$ and Andrew Smith also wrote an introductory volume on Neoplatonism..$^{7}$ For those who read Italian, another worthwhile introductory volume is a collection edited by Riccardo Chiaradonna. ${ }^{8}$

For the same readership, Chiaradonna's Italian introduction to Plotinus is certainly to be recommended. ${ }^{9}$ Unless I missed it, there has been no Englishlanguage introduction focusing just on Plotinus in the last ten years. This is reasonable enough, since the need for introductions to his thought was basically satisfied in the $1990^{\prime}$ 's. ${ }^{10}$ The same cannot be said for the other leading figure in late ancient Platonism, Proclus. ${ }^{11}$ So it was good to see the appearance of collections of papers on Proclus and his legacy ${ }^{12}$ as well as a monograph

P. Remes and S. Slaveva-Griffin (eds), The Routledge Handbook of Neoplatonism (London: Routledge, 2014).

P. Remes, Neoplatonism (Stocksfield: Acumen, 2008), and M. Tuominen, The Ancient Commentators on Plato and Aristotle (Stocksfield: Acumen, 2009).

7 A. Smith, Philosophy in Late Antiquity (London: 2004).

8 R. Chiaradonna (ed.), Filosofia tardoantica. (Rome: Carocci, 2012).

9 R. Chiaradonna, Plotino (Rome: Carocci, 2009).

10 D. O'Meara, Plotinus: an Introduction to the Enneads (Oxford: 1993); L.P. Gerson (ed.), The Cambridge Companion to Plotinus (Cambridge: 1996); L.P. Gerson, Plotinus (London, 1998).

11 Though mention should be made of L. Siorvanes, Proclus: Neo-Platonic Philosophy and Science (New Haven: Yale University Press, 1996).

12 M. Perkams and R.M. Piccione (eds), Proklos. Methode, Seelenlehre, Metaphysik (Leiden: Brill, 2006), though this is not really aimed at a wider, introductory audience. For the 
by Radek Chlup. ${ }^{13}$ Chlup's book has the considerable merit of presenting the complexities of Proclus' system in an accessible and comprehensible fashion, while also drawing frequent comparisons to Plotinus. (There remains scope for introductory volumes of this sort on other Neoplatonists, such as Porphyry, Iamblichus, and Philoponus.) With resources like these it is now entirely feasible to teach undergraduate courses on Neoplatonism or later ancient philosophy more generally. For this purpose, two collections of primary texts in translation can also be recommended: the reader on Neoplatonism published by John Dillon and Lloyd Gerson, ${ }^{14}$ and the three-volume collection of texts from the commentators edited by Richard Sorabji. ${ }^{15}$

Readers who want to go beyond introductions and readers will be grateful that so much late antique philosophical literature is now available in translation. Of course one has long had A.H. Armstrong's excellent English version of Plotinus in the Loeb series. Readers of French, meanwhile, are truly spoiled for choice when it comes to the Enneads. The publisher Flammarion offers a complete translation of Plotinus in affordable volumes, in a series overseen by Luc Brisson. In this series each treatise is given a brief introduction and the translations are annotated. A more lavish treatment is provided by the publisher Cerf. In this series, book-length studies are devoted to individual Plotinian treatises, with overall thematic introductions, translations, and detailed commentary. Among the outstanding entries in this series have been treatises I.1, I.8, V.9, or as the French would prefer to call them, treatises 53,51 , and $5 \cdot{ }^{16}$ As if this weren't enough (which, arguably, it was), Les Belles Lettres have launched a series of facing page Greek-French texts for Plotinus, along with substantial commentary. ${ }^{17}$ Another French publisher, Vrin, has been providing us with French versions of works by Porphyry, also with extensive commentary. The Sentences and To Gaurus, a work on embryology (of which more later), were covered by teams led by Luc Brisson, while the Categories commentary of Porphyry was re-edited and translated by Richard Bodéüs. ${ }^{18}$

later reception of Proclus, see S. Gersh (ed.), Interpreting Proclus from Antiquity to the Renaissance (Cambridge: Cambridge University Press, 2014).

13 Proclus: An Introduction (Cambridge: Cambridge University Press, 2012).

14 Neoplatonic Philosophy: Introductory Readings (Indianapolis: Hackett, 2004).

15 The Philosophy of the Commentators, 200-60o AD, 3 vols (London: Duckworth, 2005).

16 G. Aubry, Plotin: Traité 53 (I, I) (Paris: Cerf, 2004); A. Schniewind, Plotin: Traité $5(V, 9)$ (Paris: Cerf, 2007); D. O'Meara, Plotin: Traité ${ }^{1}$ (I.8) (Paris: Cerf, 1999).

17 Plotin, Oeuvres Complètes. Introduction; Traité 1 (I 6), Sur le beau (Paris: Les Belles Lettres, 2012);

18 L. Brisson et al., Porphyre: Sentences (Paris: J. Vrin, 2005); L. Brisson et al., Porphyre: Sur la manière don't l'embryon recoit l'âme (Paris: J. Vrin, 2012); R. Bodéüs (ed. and trans.), 
Ten years ago, relatively few works in what one might call the "Iamblichean tradition" (i.e. Iamblichus, Syrianus, Proclus and Damascius) were available in English. That has changed, with a particularly important initiative being the multi-volume translation of Proclus' Commentary on the Timaeus, perhaps the richest single Neoplatonic work apart from the Enneads. ${ }^{19}$ Another recent publication offers a useful translation of the sections of Proclus' Republic commentary devoted to poetry, ${ }^{20}$ while further Proclus translations have dealt with his comments on Hesiod and on Plato's Cratylus. ${ }^{21}$ His Commentary on the Parmenides has appeared in not one, but two new editions, one with facing-page French translation..$^{22}$ Meanwhile Proclus' teacher Syrianus is available in English as never before, with translations of his commentary on parts of Aristotle's Metaphysics - a very unusual work because of its open hostility to Aristotle, provoked by Aristotle's own criticisms of Plato-and of the evidence for his interpretation of the Timaeus and Parmenides. ${ }^{23}$ As for Iamblichus himself, his response to Porphyry's skeptical remarks on theurgy, known as On Mysteries, has appeared in English, as have the fragments of his letters found mostly in Stobaeus - these contain ideas about ethics, politics,

Porphyre: Commentaire aux Catégories d'Aristote (Paris: J. Vrin, 2008). In the nineties the same publisher already devoted volumes to the Life of Plotinus and Isagoge.

19 Published in five volumes by Cambridge University Press. The translators for the individual volumes were H. Tarrant (vol.1), D. Runia and M. Share (vol.2), and D. Baltzly (vols 3-5).

R. Lamberton (trans.), Proclus the Successor on Poetics and the Homeric Poems: Essays 5 and 6 of his Commentary on the Republic of Plato (Atlanta: Society of Biblical Literature, 2012).

21 P. Marzillo, Der Kommentar des Proklos zu Hesiods Werken und Tagen. Edition, Übersetzung und Erlaüterung der Fragmente (Tübingen: Narr, 2010); B. Duvick (trans.), Proclus: On Plato Cratylus (London: Duckworth, 2007). An honorable mention, though it didn't appear in the last decade, should be made of R. van den Berg, Proclus' Hymns: Edition, Translation, Commentary (Leiden: Brill, 2001).

22 C. Steel's appeared with Oxford University Press in three volumes, while the version of C. Luna and A.-P. Segonds, with French translation, appeared with Les Belles Lettres in five volumes. Without wishing to take sides, I must note that the rivalry between the two editorial teams was one of the more unfortunate and unedifying episodes of recent times in Neoplatonic studies. (One of the French team's volumes contains an attack on Steel's work that was described by the mild-mannered John Dillon as "a monument of malicious, nitpicking pedantry." See his discussion of the relevant volume for the online Bryn Mawr Classical Review.)

23 J. Dillon and D. O'Meara (trans.), Syrianus: On Aristotle Metaphysics 13-14 (London: Duckworth, 2006); id., On Aristotle Metaphysics 3-4 (London: Duckworth, 2008); S. Klitenic Wear, The Teachings of Syrianus on Plato's Timaeus and Parmenides (Leiden: Brill, 2011). 
and fate. ${ }^{24}$ It should also be noted that affordable reprints of a number of older studies on these Neoplatonists have been appearing under the aegis of the Prometheus Trust. ${ }^{25}$

Even with all this other activity, the most significant undertaking in terms of English translation has been the Ancient Commentators Project, led by Richard Sorabji. This series in fact includes several of the volumes just mentioned, such as Syrianus on the Metaphysics, Proclus' Cratylus commentary and socalled tria opuscula on fate and providence, and most recently Olympiodorus on the First Alcibiades. ${ }^{26}$ The bread-and-butter of the series is, however, the commentaries on Aristotle, and English versions of these make up most of the more than 100 volumes to appear so far. ${ }^{27}$ I must admit to some bias here, since I was for some years affiliated with the project when I worked at King's College London. Still, I think there is little doubt that this series as a whole has had a greater impact on the study of late ancient philosophy than any other development over the last 25 years (the first volumes appeared in 1987). It has led to a new appreciation for the philosophical interest of the commentaries, and made it far more common for scholarship on Aristotle to take account of these ancient exegetical labors. Furthermore, it has had a wide-reaching impact on the study of both Latin and Arabic medieval philosophy, since the authors of these traditions drew extensively on the commentators.

Everything I've discussed so far falls under the heading of accessibility: introductory books, handbooks, collections of primary texts, editions and translations combine to make late antique philosophy available to a far wider range of readers, including students and professional academics whose main interest is in other areas (earlier classical philosophy or medieval philosophy, for instance). But what have the specialists in Neoplatonism been doing to

24 E.C. Clarke, J.M. Dillon and J.P. Hershbell (trans.), Iamblichus: On the Mysteries (Atlanta: Society of Biblical Literature, 2003); M. Dillon and W. Polleichtner (ed. and trans.), Iamblichus of Chalcis: the Letters (Atlanta: Society of Biblical Literature, 2009). The letters have also recently appeared, with more lengthy scholarly apparatus, in Italian: D.P. Taormina and R.M. Piccione, Giamblicho: I frammenti dalle epistole. Introduzione, testo, traduzione e commento (Naples: Bibliopolis, 2010).

25 www.prometheustrust.co.uk. For instance they offer Dillon's edition and translation of the fragments of Iamblichus' De Anima commentary for $£_{30}$, and Westerink's translation of Damascius on the Philebus for $£ 24$.

26 M. Griffen (trans.), Olympiodorus: Life of Plato and On Plato First Alcibiades 1-9 (London: Bloomsbury, 2015). A remarkable recent publication offers a Greek retro-translation from Latin of Proclus' Tria Opuscula: B. Strobel, Proklos, Tria Opuscula: textkritisch kommentierte Retroversion der Übersetzung Wilhems von Moerbeke (Berlin: Walter de Gruyter, 2014). 
analyze these texts, in addition to making them accessible? There have been some clear trends, which I'll try to describe in the remainder of this overview.

Let's begin with Plotinus, who has as ever been the late ancient thinker to attract the most attention from scholars. A striking recent development in North American scholarship has been an emphasis on the influence of Gnosticism on the Enneads. The boldest argument in this direction has been made by Jean-Marc Narbonne, but the juxtaposition of the Gnostics with Plotinus was also a leitmotif of a recent a collection of papers on the influence of Plato's Parmenides. ${ }^{28}$ There is good reason to take these claims seriously: we know from the Life of Plotinus that Gnostic texts were studied in Plotinus' school, and his rivalry with the Gnostics was highlighted again by Porphyry with the title he gave to Enneads II.9: "Against the Gnostics." Of course, previous scholarship was not blind to the fact that Plotinus was engaged with the Gnostics, both positively and critically. Already in 1954, Joseph Katz wrote that "almost all of the ideas that Plotinus finds objectionable in the Gnostics have been asserted by himself in one form or another."29 The new explorations of his response to the Gnostics move beyond Plotinus' well-known ambivalence towards bodily things and conception of matter. In his monograph, Narbonne does discuss the production of matter in some detail, but he also suggests that Plotinus' views on topics such as undescended soul and demiurgic causation may respond to Gnostic ideas. ${ }^{30}$ The jury is still out on the question of just how deeply the Gnostic influence on Plotinus may run-in part because few Plotinus scholars are much acquainted with the Gnostic texts. But these recent studies should at the very least constitute a spur to further debate.

On the other side of the Atlantic, a central topic in Plotinus research has been the self. This research responds to such disparate currents as Hadot's emphasis on philosophy as a way of life, and the analytic discussions of personal identity in authors like Parfit. Apart from Sorabji's general book on the

28 J.-M. Narbonne, Plotinus in Dialogue with the Gnostics (Leiden: Brill, 2011); J.D. Turner and K. Corrigan (eds), Plato's Parmenides and its Heritage, 2 vols (Atlanta: Society of Biblical Literature, 2010). See also Gnosticism, Platonism and the Late Ancient World: Studies in Honor of John D. Turner (Leiden: Brill, 2013).

"Plotinus and the Gnostics," Journal of the History of Ideas 15 (1954), 289-98, at 289.

$30 \quad$ For a skeptical response on the topic of the demiurge see R. Chiaradonna, "Plotinus' Account of Demiurgic Causation and its Philosophical Background," in A. Marmodoro and B.D. Prince (eds), Causation and Creation in Late Antiquity (Cambridge: Cambridge University Press, 2015), 31-50. My thanks to Prof Chiaradonna for showing me an advance copy of this piece. 
self in antiquity, ${ }^{31}$ the key work in English is by one of his former doctoral students: Pauliina Remes. ${ }^{32}$ More philosophically sophisticated and compelling than another, more recent book on related themes, ${ }^{33}$ Remes' study puts the issue squarely within the context of Plotinus' metaphysics. For instance she considers whether the person in Plotinus' philosophy effectively loses its unity, being torn asunder into an intelligible or undescended self and a second empirical, embodied self. She also looks at his views on individuation of bodily substances over time. Another aspect of this focus on the self has been attention to the question of freedom or autonomy in Plotinus. A monograph by Erik Eliasson goes carefully through the whole back history of the "up to us" leading to Plotinus. ${ }^{34}$ This territory was also covered by a fascinating posthumous publication by Michael Frede, which argued that early Christian ideas about the will were really just a borrowing from the Stoics. ${ }^{35}$

These issues have received attention in other languages too. For the unity of the self, a very useful work is Gwenaëlle Aubry's commentary on Enneads I.1 for the Cerf series on Plotinus, already mentioned briefly above. ${ }^{36}$ This is effectively another monograph on the self in Plotinus. Aubry sees the Plotinian self (the "we" of treatise I.1) as a locus of shifting identification, which can see itself as embodied or as intellectual. As for the metaphysics of physical objects, both at a time and over time, this is addressed in an impressive book by Riccardo Chiaradonna. ${ }^{37}$ While it does not quite fall into the time span being considered here, having appeared already in 2002, I mention it because as an Italian language study it may not have had the readership it deserves. Chiaradonna makes a powerful case that Plotinus was adamantly opposed to Aristotle's metaphysics. In criticizing the idea of bodily things as "primary substances"

31 R. Sorabji, Self: Ancient and Modern Insights about Individuality, Life and Death (Oxford: 2006).

32 P. Remes, Plotinus on Self: the Philosophy of the 'We' (Cambridge: Cambridge University Press, 2007).

33 R. Mortley, Plotinus, Self and World (Cambridge: Cambridge University Press, 2013).

34 E. Eliasson, The Notion of That Which Depends on Us in Plotinus and its Background (Leiden: Brill, 2008).

35 M. Frede, A Free Will: Origins of the Notion in Ancient Thought, ed. A.A. Long, foreward by D. Sedley (Berkeley: University of California Press, 2011). For more on free will see the abundant recent Festschrift in honor of Carlos Steel: P. d'Hoine and G. Van Riel (eds), Fate, Providence and Moral Responsibility in Ancient, Medieval and Early Modern Thought (Leuven: Leuven University Press, 2014).

36 G. Aubry, Plotin: Traité 53 (I,1). (Paris: Cerf, 2004).

37 R. Chiaradonna, Sostanza Movimento Analogia: Plotino critico di Aristotle (Naples: Bibliopolis, 2002). 
he anticipates and rejects the attempts of other Neoplatonists to integrate Aristotle into a Platonist worldview. ${ }^{38}$

Another trend in Plotinian studies over recent years has been increased appreciation of his work in ethics, which should have put to rest the suspicion that he had little or nothing to say on this topic, apart from encouraging us to turn away from body and towards the intelligible. For a more nuanced understanding of his ethics one can do no better than to turn to Enneads I.4. This treatise has received a commentary in English by Kevin McGroarty and forms the centerpiece of a monograph in French by Alexandrine Schniewind. ${ }^{39}$ Both books, like I.4 itself, remind us that Plotinus' ethics must be understood against the background of Hellenistic ethical theories. Schniewind's focus on the figure of the ideal sage is helpful here, as is McGroarty's emphasis on the parallels between Plotinus and Epictetus. Good work has also been done on the higher realms of the Plotinian universe, with a fundamental book on nous in Plotinus by Eyjólfur Emilsson being nicely complemented by Svetla SlavevaGriffin's study of Enneads vi.6, which expounds at the numerical structuring of the intelligible world. ${ }^{40}$

So it can safely be said that Plotinus continues to be the best-studied and best-understood of all the Neoplatonists. By contrast, his student and editor Porphyry has only very recently begun to emerge as a fully rounded figure. A multi-author collection of papers on Porphyry brought together some of the leading scholars of Porphyry's thought, including Stephen K. Strange, who

38 Chiaradonna has added detail to this interpretation with subsequent work on both Plotinus and Porphyry, with publications in French, Italian and English. To pick out a few contributions in English, see his "The categories and the status of the physical world. Plotinus and the Neoplatonic commentators, in P. Adamson. H. Baltussen, and M. Stone (eds), Philosophy, Science and Exegesis in Greek, Arabic and Latin Commentaries, 2 vols (London: Institute of Classical Studies, 2004), vol.1, 121-36; "Porphyry's Views on the Immanent Incorporeals," in G. Karamanolis and A. Sheppard (eds.), Studies on Porphyry (London: Institute of Classical Studies, 2007), 35-49; "Porphyry and Iamblichus on Universals and Synonymous Predication," Documenti e studi sulla tradizione filosofica medievale 18 (2007), 123-40; and "Plotinus on Sensible Particulars and Individual Essences," in A. Torrance and J. Zachhuber (eds), Individuality in Late Antiquity (Farnham: Ashgate, 2014), 47-61.

K. McGroarty, Plotinus on Eudaimonia. A Commentary on Ennead I.4 (Oxford: Oxford University Press, 2006); A. Schniewind, L'Éthique du sage chez Plotin: le paradigme du spoudaios (Paris: J. Vrin, 2003).

40 E.J. Emilsson, Plotinus on Intellect (Oxford: Clarendon Press, 2007); S. Slaveva-Griffin, Plotinus on Number (Oxford: Oxford University Press, 2009). See also B. Collette-Ducic, Plotin et l'ordonnancement de l'être (Paris: Vrin, 2007). 
tragically died in 2009. ${ }^{41}$ His piece addresses a key question he had touched upon elsewhere too: to what extent is Porphyry's project of reconciling Aristotle with Platonism already anticipated in Plotinus? ${ }^{42}$ A major study on this general topic appeared at about the same time, with George Karamanolis' reconstruction of the whole history of the harmony thesis up to the time of Porphyry. ${ }^{43}$ Karamanolis shows that there was a wide range of views on the compatibility of the two great authorities in pre-Plotinian philosophy, but gives Porphyry a decisive role by arguing that he was the first Platonist to write commentaries on the works of Aristotle. ${ }^{44}$ Porphyry's philosophical activity has also been put in a broader context in a recent book by Aaron Johnson. ${ }^{45}$ This makes unusually extensive use of fragments from Porphyry's lost works to present a compelling picture of his views towards pagan religion and Hellenic cultural identity.

Attitudes towards the pagan religious beliefs of the later Neoplatonists have come a long way since one of the pioneers of the whole field described Iamblichus' On Mysteries as "a manifesto of irrationalism."46 Admittedly, the eyes of even the most hardened Proclus scholar may glaze over while reading Proclus' disquisition on the names of the gods in his Cratylus commentary. But this relates intimately to issues in Proclus' philosophy of language, as shown by a study of this commentary by Robbert van den Berg. ${ }^{47}$ The distinctively "pagan" topic of daimones has received a thorough study from Andrei Timotin. ${ }^{48}$ He explores how demons served mediating entities through the

41 G. Karamanolis and A. Sheppard (eds), Studies on Porphyry (London: Institute of Classical Studies, 2007).

42 On this topic see also R. Chiaradonna, "What is Porphyry's Isagoge?" Documenti e studi sulla tradizione filosofica medievale 19 (2008), 1-30.

43 G. Karamanolis, Plato and Aristotle in Agreement? Platonists on Aristotle from Antiochus to Porphyry (Oxford: Oxford Clarendon Press, 2006). See also T. Bénatouil, E. Maffi and F. Trabattoni(eds), Plato, Aristotle or Both?Dialogues between Platonismand Aristotelianism in Antiquity (Hildesheim: George Olms, 2011).

44 G. Karamanolis, "Porphyry, the first Platonist Commentator of Aristotle", in P. Adamson, H. Baltussen, M. Stone (eds), Science and Exegesis in Greek, Arabic and Latin, 2 vols (London: Institute of Classical Studies, 2004), vol. 1, 79-113.

45 A.P. Johnson, Religion and Identity in Porphyry of Tyre: the Limits of Hellenism in Late Antiquity (Oxford: Oxford University Press, 2013).

46 E.R. Dodds, The Greeks and the Irrational (Berkeley: 1951), 287.

47 R.M. van den Berg, Proclus' Commentary on the Cratylus in Context. Ancient Theories of Language and Meaning (Leiden: Brill, 2008). The notes to Duvick's translation, mentioned above in note 21, comment extensively on this aspect of the work.

48 A. Timotin, La démonologie platonicienne. Histoire de la notion de Daimon de Platon aux derniers néoplatoniciens (Leiden: Brill, 2012). 
whole history of Platonism, beginning with Plato himself. Studies like these are making it easier to integrate not only Iamblichus and his heirs into mainstream ancient philosophy, but also earlier Platonists like Plutarch. Of course the serious study of Plutarch is nothing new; there has long been a kind of cottage industry of scholarship on his vast and varied corpus. But in recent years Jan Opsomer and others have made great strides in showing his philosophical interest. ${ }^{49}$ In one interesting monograph, Plutarch's works of "popular ethics" have been recognized for their philosophical significance. ${ }^{50}$ The progress made with Plutarch is symptomatic of the inclusion of "Middle" Platonism in our understanding of later ancient philosophy. ${ }^{51}$ We have come a long way since studies like John Dillon's The Middle Platonists (published in 1977) first opened up this area of research.

A bigger challenge will be integrating the Christian tradition into the field of ancient philosophy. To some extent this remains a project for the future: scholars whose main field of interest is Patristics are not usually members of philosophy departments, even if their approach is philosophical. But it is becoming increasingly clear that no complete picture of ancient philosophy can exclude late ancient Christian thought. ${ }^{52}$ During my time writing Book Notes, there was a steady increase in the number of books I received on Christian authors. Predictably, some of the best were on Augustine, but there were also monographs on figures who wrote in Greek, such as Origen and the Cappadocians. ${ }^{53}$

49 Recent collections on him include x. Brouillette and A. Giavatto (eds), Les dialogues platoniciens chez Plutarque: Stratégies et méthodes exégétiques (Leuven: Leuven University Press, 2011); L. Roig Lanzillotta and I. Muñoz Gallarte (eds), Plutarch in the Religious and Philosophical Discourse of Late Antiquity (Leiden: Brill, 2012).

50 L. Van Hoof, Plutarch's Practical Ethics: the Social Dynamics of Philosophy (Oxford: Oxford University Press, 2010).

$5^{1}$ See for instance M. Zambon, Porphyre et le Moyen-Platonisme (Paris: J. Vrin, 2002); M. Bonazzi and J. Opsomer (eds), The Origins of the Platonic System. Platonisms of the Early Empire and their Philosophical Contexts (Louvain: Peeters, 2009).

$5^{2}$ The case has just been set out in G. Karamanolis, The Philosophy of Early Christianity (Durham: Acumen, 2013). Along the same lines, my own A History of Philosophy Without Any Gaps: Philosophy in the Hellenistic and Roman Worlds (Oxford: Oxford University Press, 2015) devotes 16 of its $5^{2}$ chapters to Christian thinkers. The above-mentioned Cambridge History also has substantial coverage of the Church Fathers.

53 Two that particularly impressed me were S.C. Byers, Perception, Sensibility, and Moral Motivation in Augustine. A Stoic-Platonic Synthesis (Cambridge: Cambridge University Press, 2013) and M. DelCogliano, Basil of Caesarea's Anti-Eunomian Theory of Names: Christian Theology and Late-Antique Philosophy in the Fourth Century Trinitarian Controversy (Leiden: Brill, 2010). A sampling of other useful studies would include A. Casiday, Evagrius Ponticus (London: Routledge, 2006); K. Corrigan, Evagrius and 
But it is not just a matter of accepting that specialism in Patristics could be one kind of expertise in ancient philosophy. In fact, and in contrast to the disciplinary arrangements typical in today's academic world, there was no stark separation between the Christian and pagan philosophical traditions of late antiquity. Of course there was extensive debate between the two religious camps, but there were also figures who, as it were, had a foot in both.

The best example is John Philoponus, who wrote both works of Christian theology and faithful reports of the exegetical study of Aristotle set forth by his master Ammonius. A revised version of a groundbreaking collection of articles on Philoponus appeared in 2010. ${ }^{54}$ His commentaries on Aristotle have been extensively covered in the Ancient Commentators Project, as have works by Aeneas of Gaza and Zacharias of Mytilene, who prefigure Philoponus' famous attack on pagan arguments for the eternity of the universe. ${ }^{55}$ Though such pagan-Christian dispute catches the eye, one could argue that (within philosophical circles at least) the transition from pagan to Christian philosophy is a story of continuity more than conflict. Without missing a beat, Greek-speaking Christians from the school of Alexandria took over the methods and interpretations of pagans like Ammonius. The ideas of the commentators also passed into other languages at this same time. One of the best recent monographs on late ancient logical commentaries is devoted to Boethius, ${ }^{56}$ and scholars have been investigating the Armenian and Syriac traditions as well. ${ }^{57}$

Gregory: Mind, Soul and Body in the 4th Century (Farnham: Ashgate, 2009); S. Harrison, Augustine's Way Into the Will (Oxford: Oxford University Press, 2006); P.E. Hochschild, Memory in Augustine's Theological Anthropology (Oxford: Oxford University Press, 2012); M.S.M. Scott, Journey Back to God: Origen on the Problem of Evil (Oxford: Oxford University Press, 2012); T. Tollefson, Activity and Participation in Late Antique and Early Christian Thought (Oxford: Oxford University Press, 2012); J. Zachhuber, Human Nature in Gregory of Nyssa: Philosophical Background and Theological Significance (Leiden: Brill, 2014).

54 R. Sorabji (ed.), Philoponus and the Rejection of Aristotelian Science (London: Institute of Classical Studies, 2010).

55 S. Gertz, J. Dillon and D. Russell (trans.), Aeneas of Gaza: Theophrastus with Zacharias of Mytilene: Ammonius (London: Bristol Classical Press, 2012). See also M.W. Champion, Explaining the Cosmos: Creation and Cultural Interaction in Late-Antique Gaza (Oxford: Oxford University Press, 2014).

56 T. Suto, Boethius on Mind, Grammar and Logic. A Study of Boethius' Commentary on Peri Hermeneias (Leiden: Brill, 2012).

57 For the Armenian tradition the main author is the fabulously named David the Invincible, who has received intense scrutiny in a series of studies from Brill: J. Barnes and V. Calzolari (eds), L'oeuvre de David l'Invincible et la transmission de la pensée grecque dans la tradition arménienne et syriaque (Leiden: Brill, 2009), A. Topchyan, David the Invincible: 
The passing of the commentary baton from pagans to Christians was smooth enough that, in many of these texts, one would scarcely be aware that one is reading a Christian author. Very late ancient pagans returned the favor by being polite towards the Christians. ${ }^{58}$ Perhaps then, the blossoming study of Christian commentators is perhaps not so much a sign of increasing openness to Christian thought in general. Rather, it is just a sign of increased willingness to treat commentaries as properly philosophical works. We have seen a number of studies devoted to the methodology and tradition of ancient commentary as such. ${ }^{59} \mathrm{~A}$ figure who looms especially large here is Simplicius, who was until recently seen as little more than a quarry for information about earlier thinkers (especially the Pre-Socratics). Now he has become an object of inquiry in his own right. ${ }^{60}$ Simplicius' contemporary Damascius has likewise come to the fore as a fascinating commentator on Plato, with a nuanced theory of pleasure and a sophisticated defense of the immortality arguments in the Phaedo. ${ }^{61}$

From all these examples we can see that researchers are achieving an increasingly complete historical picture of late antique philosophy. The same can be said on the thematic front. When we think of Neoplatonism, the topics that leap to mind are typically metaphysical: the One, emanation, the intelligible world and of the soul, matter, and so on. But as mentioned

Commentary on Aristotle's Prior Analytics (Leiden: Brill, 2010), and G. Muradyan, David the Invincible: Commentary on Porphyry's Isagoge (Leiden: Brill, 2015). For Syriac see e.g. J.W. Watt, Rhetoric and Philosophy from Greek into Syriac (Farnham: Ashgate Variorum, 2010).

58 A nice example, pointed out in J. Opsomer, "Olympiodorus," in L.P. Gerson (ed.), The Cambridge History of Philosophy in Late Antiquity, vol.2, 697-710, at 703, is Olympiodorus' irenic proposal that Christians can just understand pagan dieties as attributes of their single God.

59 For instance P. Adamson, H. Baltussen and M.W.F. Stone (eds), Philosophy, Science and Exegesis in Greek, Arabic and Latin Commentaries, in 2 vols (London: Institute of Classical Studies, 2004); W. Geerlings and C. Schulze (eds), Der Kommentar in Antike und Mittelalter, Band 1 (Leiden: Brill, 2002); special issue of Laval théologique et philosophique 64.1 and 64.3 (2008).

60 H. Baltussen, Philosophy and Exegesis in Simplicius. The Methodology of a Commentator (London: Duckworth, 2008); P. Golitsis, Les Commentaires de Simplicius et de Jean Philopon à la Physique d'Aristote (Berlin: de Gruyter, 2008).

61 G. Van Riel, Damascius: Commentaire sur le Philèbe de Platon (Paris: Les Belles Lettres, 2008); G. Van Riel, Pleasure and the Good Life (Leiden: Brill, 200o); S. Gertz, Death and Immortality in Late Neoplatonism. Studies on the Ancient Commentaries on Plato's Phaedo (Leiden: Brill, 2011). Damascius' treatise of metaphysical aporiai has also been translated into English: S. Abhel-Rappe, Damascius' Problems and Solutions Concerning First Principles (New York: Oxford University Press, 2010). 
above, Plotinus has been established as a thinker of importance in ethics. In a similar development, Proclus and his master Syrianus have been the focus of several excellent studies focusing on epistemology. Here I have in mind two Italian studies of Syrianus and Proclus by Angela Longo and Elena Gritti, and Christoph Helmig's wide-ranging study of concept formation in antiquity, which culminates with Proclus. ${ }^{62}$

An even more striking, and in some ways surprising, phenomenon has been the surge of interest in Neoplatonic physics. Whereas Plotinus' ethics or Proclus' epistemology are long-standing topics of inquiry that have recently received particular emphasis, the natural philosophy of the Neoplatonists has only just begun to emerge as a significant area for research. Leading the way here have been two excellent collections of articles ${ }^{63}$ and Marije Martijn's wonderful monograph on nature in Proclus. ${ }^{64}$ An editor of one of those two collections, James Wilberding, has also been a leading voice in this area. After publishing a detailed and sophisticated commentary on a previously overlooked cosmological treatise of Plotinus, ${ }^{65}$ he turned his attention to the apparently unpromising field of Neoplatonist embryology. This turned out to be, if you'll pardon the expression, a fertile philosophical topic, as Wilberding has shown with a translation and notes on Porphyry's To Gaurus and a separate study showing that a wide range of Neoplatonists shared an innovative embryological theory. ${ }^{66}$

With all this activity, one could be forgiven for thinking that there are no major gaps or research desiderata remaining in the field of Neoplatonic studies. But there remains much to do and much to look forward to in the next few years. As I've already implied, I believe the most significant challenge is

62 A. Longo, Siriano e i principi della scienza (Naples: Bibliopolis, 2005); E. Gritti, Proclo. Dialettica Anima Esegesi (Milan: Il Filarete, 2008); C. Helmig, Forms and Concepts. Concept Formation in the Platonic Tradition (Berlin: de Gruyter, 2012).

63 R. Chiaradonna and F. Trabattoni (eds), Physics and Philosophy of Nature in Greek Neoplatonism (Leiden: Brill, 2009), J. Wilberding and C. Horn (eds), Neoplatonism and the Philosophy of Nature (Oxford: Oxford University Press, 2012).

64 M. Martijn, Proclus on Nature. Philosophy of Nature and its Methods in Proclus' Commentary on Plato's Timaeus (Leiden: Brill, 2010). The topic is also broached in A. Lernould, Physique et Théologie. Lecture du Timée de Platon par Proclus (Calais: Septentrion, 2001).

65 J. Wilberding, Plotinus' Cosmology. A Study of Ennead II.1 (4o). Text, Translation and Commentary (Oxford: Oxford University Press, 2006).

66 J. Wilberding (trans.), Porphyry: To Gaurus on How Embryos are Ensouled, and On What is in Our Power (London: Bristol Classical Press, 2011); id. "The Revolutionary Embryology of the Neoplatonists," forthcoming in Oxford Studies in Ancient Philosophy. See also the French translation mentioned above in n.18. 
the incorporation of Christian philosophy as a recognized part of the study of ancient philosophy. One could extend the point to the later Greek philosophical tradition in Byzantium. The most recent collection of papers on Byzantine thought shows that even fundamental issues remain open. ${ }^{67}$ For instance, should we take theology to be part of the Byzantine philosophical tradition? Were the philosophers of this tradition rightly accused of being heterodox? That collection includes a paper by Dominic O'Meara on Psellos' political philosophy, a reminder that (occasional article-length studies notwithstanding) there has as yet been little effort to carry forward O'Meara's groundbreaking exploration of Neoplatonist political philosophy. ${ }^{68}$ Perhaps the next decade will see a blossoming of studies in this area, much as the last decade has with respect to Neoplatonic natural philosophy.

Speaking of natural philosophy, another intriguing potential avenue of research would be the links between medicine and philosophy in late antiquity. After all, a major advance in ancient philosophy more generally has been the embrace of Galen as a landmark philosophical, and not just medical, author. ${ }^{69}$ Given that Galen was widely read in late antiquity, and that Alexandria was the main center for both philosophy and medicine, with the result that philosophers trained there often had interests in medicine too (Philoponus is a good example), it stands to reason that there is more to discover about the relationship between these two disciplines. A major spur to this inquiry will be the series of English translations of Galen that has now begun to appear, under the general editorship of Philip van der Eijk. ${ }^{70}$

This is only one of the scholarly enterprises to anticipate in coming years. In addition to the ongoing series of translations and commentaries on Plotinus in France, mentioned above, we are also expecting a new English version

67 B. Bydén and K. Ierodiakonou (eds), The Many Faces of Byzantine Philosophy (Athens: Norwegian Institute at Athens: 2012). This is a successor volume to K. Ierodiakonou (ed.), Byzantine Philosophy and its Ancient Sources (Oxford: Oxford University Press: 2002).

68 D. O'Meara, Platonopolis: Platonic Political Philosophy in Late Antiquity (Oxford: Oxford University Press, 2005).

69 See for instance J. Barnes and J. Jouanna (eds), Galien et la Philosophie (Vandouevres: Fondation Hardt, 2003); P. van der Eijk, Medicine and Philosophy in Classical Antiquity (Cambridge: 2005); C. Gill, T. Whitmarsh and J. Wilkins (eds), Galen and the World of Knowledge (Cambridge: Cambridge University Press, 2009); C. Gill, Naturalistic Psychology in Galen and Stoicism (Oxford: Oxford University Press, 2010); P. Adamson, R. Hansberger and J. Wilberding (eds), Philosophical Themes in Galen (London: Institute of Classical Studies, 2014).

70 P.N. Singer (ed.), Galen: Psychological Writings (Cambridge: Cambridge University Press, 2013). 
of Plotinus from a team led by Lloyd Gerson. (One of the team members, George Boys-Stones, will also soon be providing us with a volume on prePlotinian Platonism which will complement Bob Sharples' very useful reader of Peripatetic thought. ${ }^{71}$ ) Parmenides Press has meanwhile launched a userfriendly series in English devoted to the treatises of Plotinus. ${ }^{72} \mathrm{~A}$ great boon to the Plotinus enthusiast will be an English version of Paul Kalligas' modern Greek commentary on the Enneads. ${ }^{73}$ Meanwhile members of the group who rendered Proclus' Timaeus commentary into English now plan to tackle his essays on the Republic. Richard Sorabji's commentators project can also be expected to produce more volumes, albeit at a slower rate than previously.

I'd like to conclude on one more positive note, which is an observation that struck me only while writing this piece. I have just been speaking of various tasks that remain to be tackled in the field of (late) ancient philosophy. These intellectual challenges pale in significance next to a cultural challenge that faces the philosophical discipline as a whole: the underrepresentation of women. In light of this, it's a great pleasure to see that so many major contributions over the past decade have been made by female scholars. One should certainly not be complacent. All philosophers, whatever their area of speciality, should be doing whatever they can to overcome the deeply entrenched lack of gender equality that currently blights the philosophical scene. But for whatever reason, Neoplatonic studies would seem to be that rare philosophical sub-discipline: a firmament whose brightest stars are as likely to be women as men. ${ }^{74}$

\section{Peter Adamson}

LMU Munich

office.peter.adamson@lrz.uni-muenchen.de

71 R.W. Sharples, Peripatetic Philosophy 200 BC to AD 200 (Cambridge: Cambridge University Press, 2010).

The first to appear was B. Fleet (trans.), Plotinus: Ennead IV.8, On the Soul's Descent into the Body (Las Vegas: Parmenides, 2012).

73 The first volume is available already: P. Kalligas, The Enneads of Plotinus: a Commentary, Volume 1, trans. E.K. Fowden and N. Pilavachi (Princeton: Princeton University Press, 2015).

74 My thanks to Chris Noble for comments on a previous draft of this paper. 